\title{
2. LA DOCTRINA DE LA CONSTITUCIÓN HISTÓRICA: DE JOVELLANOS A LAS CORTES DE 1845
}

\author{
JOAQUIN VARELA SUANZES \\ Catedrático de Derecho Constitucional \\ Universidad de Oviedo
}


SUMARIO

1. LA GÉNESIS DE LA DOCTRINA DE LA CONSTITUCIÓN HISTÓRICA: 1808-1814.-1. El Estatuto de Bayona.-2. Jovellanos y los realistas de las Cortes de Cádiz. - 3. El Manifiesto de los «Persas».-II. EL DESARROLLO DE LA DOCTRINA DE LA CONSTITUCIÓN HISTÓRICA: 1834-1845.-1. Dos versiones de la doctrina de la Constitución histórica.-2. El Estatuto Real y el Preámbulo de la Constitución de 1845.3. Historicismo y realismo social.-4. El Jovellanismo como aglutinante. - 5. La consolidación de la doctrina de la Constitución histórica en las Cortes de 1845. 
Revista de Derecho Político, núm. 39, 1995, pp. 45-79

\title{
2. LA DOCTRINA DE LA CONSTITUCIÓN HISTÓRICA: DE JOVELLANOS A LAS CORTES DE 1845
}

\author{
POR \\ JOAQUINN VARELA SUANZES \\ Catedrático de Derecho Constitucional \\ Universidad de Oviedo
}

En este artículo se va a examinar la doctrina de la Constitución histórica o tradicional de España desde su formulación jovellanista hasta su reelaboración por parte de los Diputados moderados en las Cortes de 1844-1845. Se tratará de mostrar el ropaje doctrinal con que dicha doctrina se fue revistiendo a lo largo de este medio siglo $y$ de analizar una de sus piezas claves, la soberanía compartida entre el Rey y las Cortes, de profundas consecuencias a la hora de concebir la Monarquía y, en particular, las relaciones entre el Jefe del Estado y el texto constitucional.

\section{LA GÉNESIS DE LA DOCTRINA DE LA CONSTITUCIÓN HISTÓRICA: 1808-1814}

\section{El Estatuto de Bayona}

Durante el siglo XVIII destacados exponentes de la llustración, como CAMPOMANES, ARANDA, FLORIDABLANCA, CABARRÚS, JOVELLANOS y MARTÍNEZ MARINA, habian hablado de Constitución como norma limitadora del poder regio y como criterio básico de actuación y organización del Estado. Ahora bien, este concepto de Constitución se utilizaba como sinónimo del de leyes fundamentales. Un concepto nacido a fines de la Baja Edad Media con el objeto de legitimar y limitar, a la vez, las Monarquías nacionales en ciernes, e indisolublemente unido 
a la idea de un pacto de sujeción entre el Monarca y su pueblo - que las leyes fundamentales trataban precisamente de formalizar-, en virtud del cual éste trasladaba a aquél la soberanía '. De este modo, los autores antes citados entendian por Constitución, no la suprema norma del ordenamiento, emanada del poder constituyente de la Nación, como sustentarían los revolucionarios franceses de 1789, sino la estructura normativa que resultaba de las leyes fundamentales del Reino. Una legislación tradicional en la que se delimitaba un orden político básico y, en este sentido, constitucional. Se trataba, pues, de un concepto puramente material de Constitución, muy próximo al británico, que no requería la exigencia de unos requisitos formales específicos, como acontece con el concepto moderno, ni entrañaba una connotación axiológica, como el reconocimiento de los derechos fundamentales y la división de poderes, según exigía el célebre artículo 16 de la Declaración de $1789^{2}$.

En este Concepto preliberal de Constitución, similar al viejo concepto de Leyes fundamentales, se basaría la doctrina de la Constitución "histórica" o "tradicional" de España. Una doctrina elaborada por JOVELLANOS tras la invasión napoleónica y sustentada por los Diputados realistas en las Cortes de Cádiz, por los "Persas" en su Manifiesto de $1814 \mathrm{y}$, a partir de aquí, por todo el liberalismo moderado y conservador del siglo XIX, aunque CÁNOVAS DEL CASTILLO prefiriese hablar de la Constitución «interna».

En rigor, este concepto preliberal de Constitución se había plasmado ya en el Estatuto de Bayona. Este texto era una indudable manifestación de la mentalidad constitucional de los "afrancesados", afectos casi todos ellos a los principios políticos del Despotismo llustrado. El Estatuto o Carta constitucional de Bayona - pues "carta" era y no "Constitución", en el sentido liberal del término- se concebía como una "ley fundamental" y como la base de un pacto dualista que unía a los "pueblos" con el Rey y a éste con aquéllos, como su mismo Preámbulo señalaba. En coherencia con este punto de partida, el Estatuto de Bayona, que hacía del Monarca el centro del Estado y que articulaba a las Cortes como mero órgano representativo-estamental, no contemplaba, a dife-

1 Sobre el concepto de Leyes fundamentales, vid., dentro de una amplia bibliografía, Manuel Garcia Pelayo, Del Mito y de la Razón en el Pensamiento Político, Madrid, 1968, págs. 65-140. José Antonio MaravalL, "Estado Moderno y Mentalidad Social en los Siglos XVI y XVII", Revista de Occidente, Madrid, 1972, t. I, págs. 367375. Ignacio DE OTTO, Lecciones de Derecho Constitucional (Introducción), Guiastur, Oviedo, 1980, págs. 237 y ss.

2 Sobre el concepto de Constitución en la España del siglo XVIII, vid. mi libro Tradición y Liberalismo en Martínez Marina, Caja Rural de Asturias/Facultad de Derecho de Oviedo, Oviedo, 1982, págs. 91 y ss. 
rencia de lo que dispondría el Título $X$ de la Constitución gaditana, la posibilidad de una ulterior "alteración", sino que tan sólo permitía introducir "adiciones, modificaciones y mejoras", que el Rey debía sancionar tras la deliberación y aprobación de las Cortes, como se desprendía de los artículos 85 y 156. No es extraño, por eso, que el Estatuto de Bayona, prescindiendo de lo que tenía de ilegitimidad por el problema dinástico, fuese elogiado por el pensamiento moderado posterior, de raigambre jovellanista, como un texto jurídico que unificaba tradición y modernidad $^{3}$.

\section{Jovellanos y los realistas de las Cortes de Cádiz}

Pero al examinar la génesis de la doctrina de la constitución histórica interesa centrarse en JovellaNOS. El gran pensador asturiano expuso algunos retazos de esta doctrina en su Discurso de Recepción en la Real Academia de la Historia, pronunciado en $1780^{\circ}$, pero sobre ella se manifestó sobre todo en su Consulta sobre la Convocatoria de Cortes por Estamentos, escrita en 1809, y en su Memoria en Defensa de la Junta Central y muy particularmente en sus Apéndices, redactados ambos entre 1810 y $1811^{5}$.

Como mostré en mi libro La teoría del Estado en los origenes del constitucionalismo hispánico (las Cortes de Cádiz) ${ }^{6}$, las tesis jovellanistas sobre la Constitución histórica serian sustentadas dentro de las Cortes de Cádiz por diversos Diputados realistas, unos afines al talante ilustrado y reformistas del polígrafo asturiano, como su sobrino ALONSO CAÑEDO, y otros muy alejados de él, como el valenciano BORRULL, FRANCISCO MATEO AQUIRIANO, Obispo de Calahorra, o su paisano PEDRO INGUANZO, que más tarde llegaría a ser Cardenal Arzobispo de Toledo. Asimismo, fuera de estas Cortes, las tesis jovellanistas aparecerian en nu-

3 En este punto insiste Raúl MORODo en su artículo "La reforma constitucional en Jovellanos $y$ en Martinez Marina", Boletín Informativo del Seminario de Derecho Político de la Universidad de Salamanca, n.․ 29-30, pág. 93.

4 Sobre este Discurso, vid. el comentario de Richard HerR, España y la Revolución del siglo XVIII, Aguilar, Madrid, 1979, págs. 284-5.

5 Estos documentos se citarán por la edición de la Biblioteca de Autores Españoles (BAE), Obras Escogidas de Melchor GASPAR DE Jovellanos, Madrid, 1858, t. 46. El lector puede, no obstante, consultar la reciente edición de la Memoria en Defensa de la Junta Central, que ha hecho la Junta General del Principado de Asturias, Oviedo, 1992, dos volúmenes, con un "Estudio Preliminar" y "Notas" a cargo de José Miguel Caso González.

- Centro de Estudios Constitucionales (CEC), Madrid, 1982. 
merosos documentos suscritos por realistas muy alejados del talante jovellanista. Entre estos documentos es preciso mencionar la polémica Memoria que PEDRO QUEVEDO, Obispo de Orense, envió a las Cortes, en octubre de 1811, el Manifiesto que ese mismo año redactaría el Regente Lardizábal y el escrito de JOSÉ JOAQUíN COLÓN, España Vindicada, publicado también en 1811.

En realidad, como también mostré en el libro antes citado, la teoría de las leyes fundamentales o Constitución histórica de España junto a la doctrina escolástica de la translatio imperii, inseparable de aquélla, fueron los más importantes asideros doctrinales de los sectores realistas opuestos al liberalismo doceañista desde la invasión napoleónica de 1808 hasta la restauración absolutista de Fernando VII, en 1814. Durante esta época, una y otra teoría (a las que habría que añadir el ejemplo del constitucionalismo inglés), formarian el lugar común al que se acogerian los sectores opuestos al liberalismo doceañista y a sus dos principales tesis -inspiradas ambas en el constitucionalismo revolucionario francés $y$ plasmadas en la Constitución de Cádiz-, a saber: la soberanía nacional y el concepto racional-normativo de Constitución. Dos tesis que, ciertamente, comportaban reforzar los poderes de las Cortes en detrimento de los poderes del Monarca. Exactamente lo contrario de lo que pretendían los sectores realistas.

A este respecto, creo haber demostrado que existía una común filiación doctrinal entre todos los sectores realistas, a pesar de sus diferencias políticas, esto es, ya fuesen partidarios de una reacción absolutista y castiza o de un reformismo ilustrado. Una filiación doctrinal que, en buena medida, era fruto de las excepcionales circunstancias por las que atravesaba España desde la invasión francesa, y muy particularmente a la pérdida de legitimidad de la Monarquía después de las renuncias de Bayona. Así, en efecto, para justificar el alzamiento contra el rey intruso, no servía ya invocar el principio monárquico, sino que tan sólo era posible o bien recurrir al principio de soberanía nacional, como hicieron los liberales, o bien exhumar la vieja teoria escolástica de la reasunción del ejercicio del poder por parte de la Nación mientras durase la cautividad del Monarca, así como la vieja teoría de las leyes fundamentales, como hicieron los realistas. Una doble exhumación que permitía ofrecer una solución constitucional no revolucionaria a la acefalia de la Monarquía española y establecer a la vez un límite a la acción legisladora de las Cortes.

En el libro antes citado insistía también en un hecho muy significativo: al gravitar el pensamiento realista sobre la tesis escolástica de la translatio imperii, particularmente en su versión suareziana, la más influyente en JOVELLANOS, y sobre la vieja doctrina de las leyes fundamen- 
tales, el realismo de principios del siglo XIX se distanciaba del pensamiento absolutista que había dominado el panorama intelectual durante el siglo XVIII. Este último, muy crítico con las tesis escolásticas, se había abroquelado o bien en torno a las tesis providencialistas de BOSSUET, difundidas en España por los detractores de la llustración, como ANTONIO XAVIER PÉREZ Y LÓPEZ, CLEMENTE PEÑALOSA y el primer JOAQUIN LORENZO VILLANUEVA, o bien en torno a las tesis contractualistas de SAMUEL PUFFENDORFF, sustentadas por algunos relevantes exponentes de la llustración española, como CAMPOMANES, ARANDA y FLORIDABLANCA, quienes justificaban el poder absoluto del Rey sosteniendo que el pueblo - concebido de un modo orgánico-estamental- le había había enajenado todos sus derechos.

Pero volvamos a la doctrina jovellanista de la Constitución histórica, que es el asunto que ahora interesa conocer. Para JOVELLANOS, una vez celebrado el pacto de traslación y constituida la Monarquía hereditaria, sólo en justicia podía denominarse soberano a aquel sujeto a cuyo cargo estuviese el poder ejecutivo, esto es, al Monarca. Por eso, al ser aqueIla la forma de gobierno secularmente respetada por los españoles, era una "herejía política" decir que la soberanía residía en la Nación ${ }^{7}$. Para JOVELLANOS, la Nación sólo podía aspirar al derecho de "supremacía». ¿Y en qué consistía este derecho? Pues, en primer lugar, en el poder que se reservaba la Nación a formar parte de las tareas legislativas, junto al Rey y a través de las Cortes, así como al de obligar al Monarca a cumplir las condiciones del pacto realizado entre ambas partes, que se recogía en las Leyes fundamentales del reino. El derecho de "supremacía" permitía incluso a la Nación resistir al Monarca por la fuerza y uromper por su parte la carta de un pacto ya abiertamente quebrantado por la de su contratante, recobrando asi (la Nación) sus derechos primitivos". En virtud de su "supremacía" la Nación podría asimismo reasumir —como sucedió en 1808 - la plenitud del poder, interinamente, mientras durase la ausencia del Monarca ${ }^{8}$. Tesis todas ellas que mantendrían los Diputados realistas en las Cortes de Cádiz: "Trasladada por la Nación la soberanía a su Mo-

\footnotetext{
7 Cfr. Memoria en Defensa de la Junta Central, op. cit., pág. 620. En igual sentido se expresa en la pág. 597.

8 lbidem, págs. 597 a 620 . Para sostener el derecho de resistencia de la $\mathrm{Na}$ ción española, JoveLLANOS se escuda en ulos principios generales admitidos en la política". Ibidem, pág. 620. Pero en estos postulados es patente la influencia de la Escuela Española del Derecho Natural. Una influencia que el publicista asturiano prefiere no citar, quizá, como apunta SánCHEz Agesta, "por supervivencia de aquel prejuicio contra lo que el siglo XVIII llamó doctrina jesuitan. El pensamiento político del Despotismo llustrado, Instituto de Estudios Políticos (IEP), Madrid, 1953, pág. 224. También se apoyaba Jovellanos en las Partidas y en Aristóteles, ibidem, pág. 620.
} 
narca elegido — decía, por ejemplo, el Obispo de Calahorra-queda éste constituido soberano de su nación, y nadie le puede deponer del derecho de soberanía, mas debe observar fielmente las condiciones y pactos que le están impuestos por las leyes fundamentales del reyno" ${ }^{9}$.

Las leyes fundamentales, pues, venían a suponer el título merced al cual el Monarca ostentaba su potestad regia; el documento que instituía la Monarquía como forma de gobierno de la Nación española, la cristalización o plasmación juridica del contrato que aquél había celebrado con éste. El poder del Monarca y el de la Nación -aquél in actu, éste in radice - se recogían en estas leyes históricas, expresión normativa del pacto entre el Rey y su Reino: "La Nación española - decía a este respecto el realista LERA en las Cortes de Cádiz - con igual libertad y derecho que las demás, quiso elegir una persona para que la gobernara, instituyendo una Monarquía baxo el pacto y las condiciones que forman las leyes fundamentales de nuestra antigua Constitución" "

Pero además de esta función fundamentadora o legitimadora de la Monarquía, las leyes fundamentales tenían una función limitadora. Contenían las condiciones bajo las cuales el Rey y la Nación, representada en Cortes, debían ejercer el poder. $Y$ una de estas condiciones -la más importante- consistía en que las facultades legislativas debería compartirlas con las Cortes. Pero a la vez las leyes fundamentales expresaban los límites del poder de la Nación y, por tanto, de las atribuciones de las Cortes. $Y$ en este sentido significaban una garantía del poder del Monarca. Eran, pues, prueba de que ambos poderes se circunscribirian a actuar en sus respectivas esferas y se sujetarían a las condiciones estipuladas dando lugar a una forma de gobierno ensalzada por su templanza y equilibrio: la "Monarquía moderada". Este doble carácter limitador atribuido a las leyes fundamentales está muy claro en JOVELLANOS, para quien, una vez celebrado el contrato entre el Monarca y la Nación, en el que ésta le prescribía a aquél "ciertos límites y señalado determinadas condiciones" en el ejercicio del poder, "resultará que si la nación así constituida tiene una obligación perpetua de reconocer y obedecer aquel poder, mientras obre según los términos del pacto, tendrá también un derecho perpetuo para contenerlos en aquellos términos" ".

Por consiguiente, si el Rey no podía legislar sin el consentimiento de la Nación reunida en Cortes, éstas, además de verse obligadas a res-

- Diarios de las Discusiones y Actas de las Cortes (DDAC, en adelante), Cádiz, en la Imprenta Real, t. 8, pág. 61.

${ }_{10} D D A C$, t. 8, pág. 76.

1 Memoria..., op. cit., pág. 620. 
petar el poder ejecutivo del Monarca, tampoco podian legislar sin su consentimiento, a no ser en ausencia del Monarca, como ocurría entonces, durante la cual las Cortes reasumian la plenitud del poder legislativo. En cualquier caso, las Cortes por separado no podrían modificar la "esencia" de la Constitución histórica. Su cometido estaba limitado a "mejorarla». Así lo decia JOVELLANOS en uno de los párrafos más conocidos de su obra: "Y aquí notaré que oigo hablar mucho de hacer en las mismas Cortes una nueva Constitución y aun de ejecutarla, y en esto sí que, a mi juicio, habria mucho inconveniente y peligro. ¿Por ventura - se preguntaba JOVELLANOS- no tiene España su Constitución? Tiénela, sin duda, porque ¿qué otra cosa es una Constitución que el conjunto de leyes fundamentales que fijan los derechos del soberano y de los súbditos y los medios saludables para preservar unos y otros? ¿Y quién duda que España tiene estas leyes y las conoce? ¿Hay algunas que el despotismo haya atacado y destruido?, restablézcanse. ¿Falta alguna medida saludable para asegurar la observancia de todas? Establézcanse. Tal será siempre en este punto mi dictamen sin que asienta a otros que so pretexto de reformas traten de alterar la esencia de la Constitución española. Lo contrario no cabe en el poder de Vuestra Majestad, que ha jurado solemnemente observar las leyes fundamentales del reino, ni en los votos de la Nación..." 12. En estas tesis insistirian los Diputados realistas en las Cortes de Cádiz: "La Nación española —decía, por ejemplo, LLANERA- está constituida, tiene $y$ ha tenido siempre su constitución o leyes fundamentales... y si las leyes fundamentales de la Monarquía o su Constitución necesita mejorarse, esto mismo supone su actual existencia..." "13. "Hallo también graves dificultades -añadía BORRULL- en declarar que al presente le pertenece a la Nación el derecho de establecer sus leyes fundamentales, pues las tiene establecidas, y muy sabias, siglos ha, y no puede por sí sola variar alguna de ellas" ${ }^{14}$.

De esta manera se negaba el carácter constituyente de las Cortes, reivindicado por los liberales doceañistas en virtud del principio de soberania nacional. En realidad, aunque no lo formulasen de forma tan explícita, para JOVELLANOS y para los Diputados realistas, ni siquiera el

12 Ibidem, pág. 599. Para Jovellanos, supuesta la existencia de una Constitución, "y su fiel observancia por las autoridades establecidas en ella, ni la sana razón, ni la sana política, permiten extender más allá los límites de la supremacia, o llámese de soberanía nacional, ni menos atribuirle el derecho de alterar la forma y esencia de la Constitución recibida y destruida para crear otra nueva; porque, ¿fuera esta otra cosa que darle el derecho de anular por su parte un pacto por ninguna otra quebrantado, y de cortar sin razón y sin causa los vinculos de la unión social?". lbidem, pág. 621.

${ }_{13}$ DDAC, t. 8, pág. 21.

${ }^{14}$ Ibidem, t. 8, págs. 54-5. 
Rey y las Cortes de común acuerdo podrían modificar las leyes fundamentales, "esencia" de la Constitución histórica o tradicional, al ser el fundamento del poder de ambas instituciones. Tan sólo les era lícito acomodarlas a las nuevas circunstancias. De este modo, el polígrafo asturiano y algunos de sus seguidores en las Cortes de Cádiz, como INGUANZO, BORRULL, BECERRA Y LLAMAS, y CAÑEDO, venían a negar la idea misma de poder constituyente. La facultad de crear ex novo una Constitución haciendo tabla rasa de la legalidad fundamental existente se rechazaba sin paliativos. No es, repárese bien, que el poder constituyente debiese recaer en las dos instituciones tradicionales, las Cortes y el Rey, pilares de la Constitución histórica española, sino que tal poder se desechaba. Las Cortes y el Rey, como sujetos co-soberanos (lo que jurídicamente no dejaba de ser una contradicción en los términos), tan sólo podian reformar la Constitución tradicional decantada por la historia, con el objeto de actualizarla, de ponerla al día. Las Cortes y el Rey, en definitiva, sólo podrian llevar a cabo la reforma de la Constitución, pero sin alterar su esencia, esto es, sobre todo, su carácter monárquico tradicional, la confesionalidad católica del Estado y el status de sus estamentos. "Hay leyes, Señor - señalaba INGUANZO en las Cortes de Cádiz-, que son por su naturaleza inalterables en todo evento, y otras, al contrario, que pueden y deben variarse en todos los tiempos $y$ las circunstancias. A la primera clase pertenecen aquellas que se llaman, y son realmente, fundamentales, que constituyen los fundamentos del Estado, y destruidas ellas se destruiría el edificio social. A la segunda pertenecen todas las demás...n ${ }^{15}$.

Las leyes fundamentales que recogían el pacto fundacional de la Monarquía celebrado entre el Rey y el Reino reunido en Cortes (estamentales), aun siendo inicialmente consentimiento, lo que las defendía de la arbitrariedad regia, se transformaban luego en historia, lo que las resguardaba del consentimiento in actu y de las alteraciones que resultarían de él. La historicidad de las leyes fundamentales o Constitución histórica de la Monarquia les permitía estar a salvo de futuros pactos: ya de ratificación, ya de rectificación. El negar el poder constituyente de las Cortes de Cádiz para dar una "nueva" Constitución no se debía sólo a que, ante la cautividad de Fernando VII, faltaba una de las partes contratantes. No era, en rigor, un problema de consentimiento imperfecto, sino que el consentimiento, aun siendo perfecto, no podía primar sobre la historia. Es decir, sobre los consentimientos anteriores de aquellos que habian hecho posible el pacto y de aquellos otros que lo habían respetado y aun de los que potencialmente podrian llegar a respetarlo en el futuro, los nasciturus.

$15 D D A C$, t. 9, pág. 58. 
No muy distinta era la posición de EDMUNDO BURKE, un autor muy afín a JOVELLANOS, como lo eran en general los tratadistas de la Constitución británica ${ }^{16}$. En sus Reflections on the Revolution in France es bien patente la idea de perpetuidad de un orden jurídico básico, constitutivo o fundamentador del Estado, el cual debía convertirse «en una asociación (partnership) no sólo entre los vivos, sino también entre los vivos $y$ los muertos $y$ aquellos que van a nacer" ${ }^{17}$.

De este modo, tampoco BURKE admitía la existencia de un poder constituyente, el ariete conceptual más importante de toda la teoría constitucional elaborada por los revolucionarios franceses y la premisa que mejor ponía de manifiesto la primacia de la razón y de la voluntad democráticas sobre la historia. Para BURKE, como para JOVELLANOS y para los Diputados realistas, se podía mejorar, pero no innovar. Se podía reformar, pero no destruir: "Lo que nosotros mejoramos —escribe BURKE- no es jamás completamente nuevo, y lo que conservamos no es nunca completamente viejo. Quedamos así vinculados por estos principios a nuestros mayores... Adoptando este principio de herencia, hemos dado (los ingleses) a la trama de nuestra política el carácter de una relación consanguínea, uniendo la Constitución de nuestro país con nuestros vínculos familiares más queridos. Hemos hecho a nuestras leyes fundamentales un sitio en el seno de nuestros sentimientos familiares" ${ }^{18}$. Unas ideas muy parecidas a las que JOVELLANOS confesaba a LORD HOLLAND: "Nadie más inclinado que yo a restaurar $y$ afirmar y modificar; nadie más timido en alterar y reformar... Desconfío mucho de las teorías politicas y más de las abstractas. Creo que cada nación tiene su carácter; que éste es el resultado de sus antiguas instituciones; que si con ellas se altera, con ellas se repara" ${ }^{19}$.

Ahora bien, es claro que la doctrina de las leyes fundamentales o de la Constitución histórica, tal como la expusieron JOVELLANOS y los

18 Sobre la filiación doctrinal de Jovellanos, vid., dentro de una amplia bibliografia, la reciente obra de Javier VARELA, Jovellanos, Alianza, Madrid, 1989, particularmente el cap. IX. Este libro, sugestivo e innovador, carga las tintas, a mi juicio, sobre el influjo liberal y anglófilo en el pensamiento constitucional de Jovellanos, sin destacar suficientemente otras fuentes doctrinales presentes en las ideas constitucionales jovellanistas, como las de carácter escolástico. Un reproche sobre el que me extiendo en mi artículo «Un precursor de la Monarquía Parlamentaria: Blanco-White y "El Español" (1810-1814)", Revista de Estudios Políticos (REP), n. 79 , Madrid, 1993.

17 Reflections on the Revolution in France (1790), edición de Penguin Books, con una Introducción de Cruise O'Brien, Londres, 1983, pág. 194.

18 Ibidem, pag. 120.

19 Correspondencia con Lord Vasall Holland, en Obras..., op. cit., t. 86, 1956, pág. 337. Sobre las relaciones entre Jovellanos y Lord Holland me extiendo en mi artículo Un precursor de la Monarquía parlamentaria..., op. cit. 
Diputados realistas, no conducía necesariamente a una oposición frontal a la elaboración de un texto constitucional escrito, racionalmente trazado $y$ articulado ${ }^{20}$. Mucho menos cuando, como acontecía en 1810 , tal elaboración era un hecho inevitable, al que había que hacer frente. Pero en este supuesto, las leyes fundamentales o Constitución histórica se contraponían al texto constitucional escrito o Constitución formal. Aquéllas se convertian en parámetro de ésta. La Constitución formal debía recoger, so pena de ilegitimidad, los principios básicos de las leyes fundamentales de la Monarquía, adecuándolas a las cambiantes circunstancias históricas, sin alterar en ningún caso su esencia. Uno de esos principios básicos era, sin duda, la soberanía compartida entre el Rey y las Cortes, el pilar sobre el que se asentaba la "Monarquía moderada", una forma de gobierno que, a juicio de BORRULL, existía en España desde los comienzos de la Alta Edad Media: “... Después de la invasión de los sarracenos -argüia este Diputado- se levanta la Monarquía de Asturias, y la soberanía está dividida entre el rey y la nación, y ambos de conformidad hacen las leyes" ${ }^{21}$.

Por encima de estas dos instituciones decantadas por la historia, expresión fidedigna de la tradición española, no podía haber poder alguno. Sólo a ellas, como auténticos co-soberanos, tocaba, por tanto, dar un texto constitucional o reformarlo. De esta forma, se reivindicaba la «flexibilidad constitucional», típica del constitucionalismo inglés -o la "omnipotencia parlamentarian, como se llamaria más tarde-, y se negaba (o se aceptaba de forma puramente instrumental, como se verá) una de las más relevantes premisas del ideario constitucional del liberalismo doceañista, cuyo origen se encontraba en SIEYES y en las doctrinas sustentadas por los constituyentes franceses de 1791, a saber: la distinción entre unas Cortes Constituyentes, unas Cortes ordinarias y unas Cortes de revisión, así como, consiguientemente, entre las leyes constitucionales $y$ las leyes ordinarias.

Pero la defensa de la flexibilidad constitucional iba inseparablemente ligada a la defensa de los límites materiales de la reforma constitucional. Del mismo modo que las leyes fundamentales constituian un punto de partida insoslayable a la hora de elaborar el texto constitucional, era preciso respetar también los artículos constitucionales que supuestamente las recogían, e impedir su reforma. Las Cortes con el Rey podrían modificar en adelante los preceptos constitucionales con las mis-

20 Oposición que harían los tradicionalistas alemanes, como De Bonald, De Maistre, Von Haller, en parte por (mal) interpretar a Burke en clave reaccionaria y no en clave conservadora, como había hecho Jovellanos y como haria más tarde, según veremos, Antonio Alcalá Galiano.

${ }^{21}$ DDAC, t. 8, pág. 57. 
mas formalidades que las leyes ordinarias, pero el poder de ambas instituciones no era suficiente par reformar los preceptos "fundamentales" o "esenciales «incluidos en el texto constitucional, sino tan sólo los «subalternos "o "secundarios".

El catalán ANER distinguia, así, dentro de las leyes constitucionales, entre aquellas que debían ser "perpetuamente estables, cuales son las que determinan los derechos de los ciudadanos, su religión, la forma de gobierno, etc." y otras "menos estables", como, por ejemplo, "las que determinaban las cualidades que debían tener los Diputados en Cortes". La reforma de estas últimas, si bien posible, debía ser más difícil que la de las leyes no incluidas en el código constitucional, pues de lo contrario "no sería fácil conservar inalterables los principios constitutivos de la Monarquía moderada" ${ }^{22}$. VILLANUEVA se pronunció también a favor de dificultar la reforma de los preceptos constitucionales no "esenciales", pero con el mismo objeto al que se había referido ANER, esto es, el de "perpetuar las bases fundamentales de nuestra constitución... cuales son, por ejemplo, la monarquía moderada y la unidad de la religión católica, las cuales mira y mirará España como esenciales a su constitución". ANER y VILLANUEVA, pues, admitían de forma puramente instrumental una cierta rigidez constitucional. INGUANZO, en cambio, aun coincidiendo en la necesidad de asegurar la permanencia de los preceptos "esenciales" del texto constitucional, se pronunció en contra de dificultar los preceptos "secundarios": "Las leyes constitucionales que por su naturaleza y esencia son variables - argumentaba este Diputado- podrán variarse siempre que convenga, por más que el legislador quiera y mande que nunca se varíen... Pero las leyes que de suyo y esencialmente son y deben ser perpetuas irrevocablemente, éstas sí que deben constituirse de un modo que no puedan revocarse jamás" ${ }^{23}$.

La renuencia a aceptar unos limites adjetivos o formales a la reforma constitucional (o, en el caso de algunos realistas, su aceptación puramente instrumental $y$ ajena por completo al telos garantista consustancial al concepto racional- normativo de Constitución defendido por los Diputados liberales), suponía una garantía de que esta reforma se sometería a unos límites sustantivos o de contenido, mediante los cuales se preservaba la inmutabilidad de ciertos principios e instituciones considerados esenciales a la "verdadera constitución" e incluidos en el texto constitucional o "constitución formal", posterior e inferior a aquélla. La permanencia de las Cortes y el Rey $y$ de los principios fundamentales que estas instituciones salvaguardaban —como la propiedad y la religión 
católica-, se aseguraba, efectivamente, por el sólo hecho de afirmar su exclusiva competencia para llevar a cabo la reforma del texto constitucional. Al postular estas premisas, en efecto, se sustraía a estas dos instituciones de toda posible modificación constitucional. Se trataba de dos instituciones anteriores y superiores al documento constitucional o "constitución formal", protagonistas de su elaboración y cambio. El Rey y las Cortes elaboraban y reformaban la "constitución formal" y en consecuencia no podían ser excluidos (ni autoexcluirse) de ella, pues lo contrario supondría violar su soporte legitimador. El texto constitucional debía limitarse, así, a formalizar unas relaciones de poder preexistentes, decantadas por la historia, que descansaban en el poder conjunto del Rey y las Cortes, a quienes se imputaba el supremo poder político. Una imputación que alargaba el viejo dualismo estamental, basado en el binomio rex-regnum, como alternativa a la moderna teoría monista de la Monarquía constitucional, para la cual el Rey es un órgano creado por la Constitución, esto es, por la voluntad constituyente de la Nación, de quien deriva el supremo e indivisible poder del Estado.

De esta manera, la Constitución de una comunidad no se reducía ni identificaba, como había sostenido el liberalismo revolucionario francés y el liberalismo doceañista español, con un conjunto normativo sistemática y racionalmente trazado, fruto de la voluntad del cuerpo social. $\mathrm{Ni}$ siquiera ese conjunto normativo significaba su principal exponente. La "verdadera" Constitución era la "histórica", las antiguas leyes fundamentales de la Monarquía. Las leyes escritas y sistematizadas en un código debían limitarse a ser la expresión documental de este cuerpo legal histórico.

Es preciso señalar, por último, que este concepto tradicional, histórico, de Constitución iba estrechamente unido a un concepto sociológico (conservador, ciertamente) de la misma. La Constitución histórica, el orden histórico que se normativizaba y se contraponía al orden legal reflejado en la Constitución formal, no era un orden del pasado. Era un orden más bien intemporal, ucrónico. Expresaba lo esencial del pasado que él detenia y retenia: era el pasado-presente que pretendía conservase en el futuro. Por eso al defender ese orden histórico, tradicional, y las instituciones políticas que le eran consustanciales, el Rey y las Cortes, copartícipes de la soberania, se defendían también las relaciones de poder presentes, existentes. Eran dos enfoques distintos, pero compatibles, complementarios. En las Cortes de Cádiz lo mostró INGUANZO, quizá el realista más inteligente de todos, para quien las instituciones públicas debían adaptarse siempre a la naturaleza de cada sociedad y a su forma de gobierno, coincidiendo con el criterio de BURKE y de JOVELLANOS. Era preciso por ello que el texto constitucional en ciernes vertebrase unas Cortes bicamerales al estilo británico — que antes había defendido JOVE- 
LLANOS-, capaces de configurar "una fuerza intermedia que reúna los intereses de todos", según había aconsejado MONTESOUIEU, y de conjugar todas las formas de gobierno, la Monarquia, la aristocracia y la democracia, como acontecía en una auténtica monarquía "mixta" o "moderada". "Las instituciones, Señor, de cualquier Estado - decía INGUANZO- deben ser análogas al carácter y naturaleza de su gobierno. Unas son las que convienen a la Monarquía, otras las que se adaptan a la democracia. Un Estado monárquico es un Estado jerárquico. Las diferentes clases en que se divide son los elementos que le componen, $y$ forman aquella armonia y enlace de unos miembros con otros... Desengañémonos, Señor, si alguna cosa puede consolidar las Cortes, darles su vigor $y$ energía, y hacerlas respetables, es su constitución intrínseca, orgánica: que no sean una masa informe y confusa, sino un compuesto de partes o miembros combinados, que reúna la potencia de cada uno, es decir, la fuerza de todas las formas de gobierno" ${ }^{24}$. Pero la mixtura del concepto histórico y sociológico de Constitución se haría de forma mucho más clara en la doctrina constitucional del liberalismo moderado $y$, en particular, en las Cortes de 1844-1845, como tendremos ocasión de comprobar oportunamente.

\section{El «Manifiesto de los Persas»}

Digamos ahora que en el período fundacional del constitucionalismo español, la doctrina de la constitución histórica, aparte de en el Estatuto de Bayona, en los escritos de Jovellanos y en las intervenciones de los Diputados realistas en las Cortes gaditanas, se recogió también en un documento de notable importancia: el llamado "Manifiesto de los Persas". Un documento que en el mes de abril de 1814 suscribieron sesenta y nueve miembros de las Cortes Ordinarias ${ }^{25}$. Sus signatarios, a la cabeza de los cuales figuraba BERNARDO MOZO DE ROSALES, su probable

${ }^{24} D D A C$, t. 8 , págs. 266-7.

${ }_{25}$ Representación y Manifiesto que algunos Diputados a las Cortes Ordinarias firmaron en los mayores apuros de su opresión... Madrid, 12 de abril de 1814. Vid. el texto completo del "Manifiesto" en Vicente MARRERo, El tradicionalismo español del siglo XIX, Madrid, 1955, págs. 1-68. El "Manifiesto de los Persas" - nombre con que se conoceria más adelante, debido a que su primer párrafo comenzaba con las palabras: "... Era costumbre entre los antiguos persas...n- es para M. ARTOLA «la primera declaración programática de lo que si no es aún un partido organizado, es, cuando menos, un grupo parlamentario, como to pone de manifiesto el encabezamiento original", Partidos y Programas Políticos. 1808-1836, Aguilar, Madrid, 1977, pág. 205. 
redactor, ponian en la picota la obra de las Cortes constituyentes $y$, en particular, el texto constitucional de 1812, por entender que no habia hecho más que introducir en España las ideas subversivas e impias de la Revolución francesa, ajenas por completo a la tradición nacional española. Pero además de denunciar la obra de la Asamblea gaditana - a cuyos Diputados liberales acusaban de haber estado "poseidos de odio implacable a las testas coronadas"-, los "Persas" solicitaban que se convocasen unas nuevas Cortes por estamentos con el objeto de articular una Monarquía verdaderamente limitada o moderada, no por una "Constitución", sino por las antiguas "Leyes Fundamentales", en las que, a su juicio, debería reactualizarse el pacto o contrato suscrito entre el Reino y el Rey, de acuerdo en todo con las tesis jovellanistas, de impronta suareziana, que en las Cortes Extraordinarias de Cádiz habían defendido los Diputados realistas. Los firmantes de este Manifiesto no ponian en entredicho la soberanía del Rey ni la Monarquía absoluta - a la que calificaban de "obra de la razón y de la inteligencia"-, sino que se limitaban a aconsejar su moderación y templanza mediante unas Cortes estamentales y unos limites extremadamente vagos, que históricamente habian demostrado con creces su inoperancia, sin que faltase tampoco un alegato a favor del restablecimiento del Tribunal de la Inquisición, "protector celoso y expedito para mantener la Religión, sin la cual no puede existir ningún gobierno" ${ }^{26}$.

\section{EL DESARROLLO DE LA DOCTRINA DE LA CONSTITUCIÓN HISTÓRICA: 1834-1845}

\section{Dos versiones de la doctrina de la Constitución histórica}

La doctrina de la Constitución histórica elaborada por JOVELLANOS fue recogida tanto por los carlistas como por los liberales moderados. Ello dio lugar a dos versiones de esta teoría, que presentan entre sí notables diferencias, aunque también notables similitudes. La versión

26 Para insertar este "Manifiesto" en su contexto histórico-constitucional, vid. mi artículo "La Teoría constitucional en los primeros años del reinado de Fernando VII: el Manifiesto de los "Persas" y la "Representación" de Álvaro Flórez Estrada", en el Libro-Homenaje al Profesor José Miguel Caso González, Oviedo, 1994 (en prensa). 
carlista enlaza con las tesis que habían sustentado en Cádiz los realistas más alejados de la llustración, como el valenciano BORRULL y el asturiano INGUANZO, aunque su principal antecedente se hallaba en el Manifiesto de los "Persas". En esta versión se acentuaban los rasgos inmovilistas consustanciales a la doctrina de la Constitución histórica. Se mantenía, así, de forma más implícita que explícita, puesto que la pobreza argumental del carlismo fue notable, el originario componente escolástico propio de la teoría de las leyes fundamentales; persistía el organicismo (tanto estamental como territorial) y la argumentación teocrático-religiosa a la hora de justificar la realeza (compatible con el pactismo tradicional), la función directora de la Iglesia en el Estado y la intolerancia religiosa. La doctrina de la Constitución histórica, pues, se trató de mantener sin contaminación liberal alguna, rechazando de plano la limitación del Monarca mediante un texto constitucional escrito. Defender la Constitución tradicional de España suponía defender la institución monárquica, limitada por unas Cortes que se concebían como la tradicional institución representativa del reino (no de la Nación), esto es, como la institución que ante el Rey representaba tanto a los estamentos (y a sus privilegios) como a los diversos territorios (y a sus fueros) de las Españas. Aunque el foralismo fue muy impreciso hasta que no se articuló de forma sólida con las elaboraciones de ENRIQUE GIL ROBLES y VÁZQUEZ DE MELLA.

Esta versión de la doctrina de la Constitución histórica se hace patente en algunos documentos que vieron la luz en el Trienio Liberal, como el Manifiesto que publicó la llamada "Regencia Suprema de España durante la cautividad de Fernando VII» y el denominado "Manifiesto de Eroles", por ser su autor el Barón de este nombre. Las ideas principales que conforman esta versión de la doctrina de la Constitución histórica vuelven a hacer acto de presencia en diversas proclamas publicadas al socaire del levantamiento "dels malcontents", en 1827, así como en la Circular que los partidarios de Don Carlos Maria Isidro de Borbón redactaron en 1833, tras la revocación de la Pragmática Sanción y el restablecimiento de las Leyes de Partida.

En la versión de la doctrina de la Constitución histórica sustentada por el liberalismo moderado, que es la única que ahora interesa examinar, se intentó conciliar la teoría premoderna de la Constitución histórica con algunas premisas básicas de la teoría constitucional elaborada por el liberalismo. Ésta era sin duda la versión más afín a JOVELLANOS y a los realistas más cercanos a la llustración presentes en las Cortes de Cádiz (como CAÑEDO y el gallego BECERRA Y LLAMAS), e incluso con la teoría constitucional de los "afrancesados", recogida en el Estatuto de Bayona. De hecho, los jovellanistas ilustrados, los "afrancesados" y los carlistas menos extremos, junto a los liberales desengañados $y$ templados 
por el exilio y el Trienio, formarían las filas del Partido Moderado en los años treinta y cuarenta del pasado siglo ${ }^{27}$.

En esta versión se mantenía como un punto nodal el principio de la soberanía compartida entre el Rey y las Cortes, frente al dogma progresista de la soberanía de la Nación, recogido en la Constitución de 1837, si bien de forma menos diáfana que en la Constitución de Cádiz ${ }^{28}$. De igual modo, se conservaba el historicismo inmovilista a la hora de mantener la idea de Constitución histórica como parámetro básico de toda la legalidad estatal. No obstante, la interpretación de la tradición histórica se hacía compatible con las nuevas exigencias socio-políticas. Así, la defensa de una Constitución histórica se cohonestaba con la existencia de un texto constitucional escrito, elaborado de acuerdo con las dos instituciones históricas, el Rey y las Cortes, en quienes residía la soberanía. La confesionalidad católica del Estado se concilió con una cierta tolerancia religiosa e incluso desde 1834 a 1840, en plena operación desamortizadora, con un anticlericalismo a veces pasivo y un tanto vergonzante. La Corona, encarnada en Isabel II y sus sucesores, se configuraba como un poder limitado por unas Cortes representativas de toda la Nación (y no del Reino), de acuerdo con unos esquemas uniformistas e individualistas, llevados a la práctica por hombres como JAVIER DE BURGOS, CEA BERMÚDEZ y BRAVO MURILLO, aunque el componente estamental no se eliminase del todo al delimitarse la composición del Senado y al concebirse su función en el seno de las Cortes. Se eliminaba toda concepción teocrática del poder $y$ se transformaba a los súbditos o vasallos en ciudadanos, a los que se reconocía por igual, no unos derechos "políticos» -reservados a una minoría de varones propietarios-, pero sí unos derechos civiles, de acuerdo con el principio básico de igualdad legal, esto es, con independencia de la posición económico-social de los ciudadanos $y$ de los territorios en los que éstos se insertaban.

\section{El Estatuto Real y el Preámbulo de la Constitución de $\mathbf{1 8 4 5}$}

La doctrina liberal-moderada de la Constitución histórica se manifiesta ya en la «Exposición» que precede al Estatuto Real. La apelación a

27 Sobre la formación del Partido Moderado es de obligada consulta la obra de Espin Cánovas, El Partido Moderado (CEC), Madrid, 1982. Respecto de la evolución del constitucionalismo español durante estos años, vid. mi artículo "La Constitución de Cadiz y el liberalismo español del siglo XIX", Revista de las Cortes Generales, n.․ 10, 1987.

${ }_{28}$ Sobre este particular, vid. mi artículo "La Constitución española de 1837: una Constitución transicional», publicado en el n. .20 de esta misma revista. 
las Leyes fundamentales o Constitución histórica de España, en la que se asienta el texto del Estatuto o "Constitución formal", es clara, aunque no del todo explícita. En esta «Exposición» se reserva a la Reina Gobernadora, y no a la Nación, como acontecía en el "Discurso Preliminar" a la Constitución de 1812, el restablecimiento de las "antiguas leyes fundamentales", para que, juntamente con las Cortes, las actualicen y mejoren. El Estatuto no consagraba, por ello, el principio monárquico, tal como había ocurrido con la Carta francesa de 1814, sino la doctrina de la soberanía compartida entre el Rey y las Cortes. No era, pues, el Estatuto una "Carta otorgada" graciosamente por la Corona - como denunciaba el sector progresista del liberalismo español-, sino una "carta pactada" entre la Corona y las Cortes, instituciones "soberanas" cuyas relaciones constitucionales el Estatuto Real no hacía más que "reactualizar», sobre la base del derecho histórico, particularmente de las Leyes de Partida, que la propia "Exposición" cita, y de las demás leyes fundamentales del Reino. El Estatuto, en definitiva, no ponía en planta una Monarquía limitada, al estilo de las alemanas, sino una Monarquia constitucional, similar a la de la Carta francesa de 1830.

MARTÍNEZ DE LA ROSA, el principal autor del Estatuto, insistiría en esta interpretación en las Cortes reformistas de 1845. A su juicio, se habian equivocado los que en su día habían creído que el Estatuto Real era una "concesión» de la Corona, que, por tanto, "podía retirarse el día que la voluntad real así lo quisiera». A su entender, el Estatuto no se había presentado "como una merced voluntaria y espontánea, a pesar de que nacía de la voluntad plenísima de la Corona, sino como el cumplimiento de las antiguas leyes de la Monarquia; leyes que habían unido con lazos indisolubles a dos grandes poderes de la Nación: a las Cortes y a la Corona» ${ }^{29}$.

Fue, no obstante, en el "Preámbulo" de la Constitución de 1845 - redactado por DONOSO CORTÉS, que actuó en aquellas Cortes como Secretario de la Comisión Constitucional-en donde de forma más clara y acabada se recogió la doctrina de la Constitución histórica o tradicional de España y, con ella, el principio de "soberanía compartida»: "... Siendo nuestra voluntad - la de la Reina Isabel II- y la de las Cortes del Reino regularizar y pone en consonancia con las necesidades actuales del Esta-

29 Diario de Sesiones de las Cortes (DSC, en adelante), 11 de noviembre de 1844, pág. 388. El profesor VILLAROYA, el más minucioso estudioso del Estatuto, sostiene una tesis similar, cfr. El sistema político del Estatuto Real, IEP, Madrid, 1968, págs. 95 y ss., 117 y ss., 379-383, y 619 y ss. En igual sentido, L. SÁNCHEZ AGESTA, Historia del Constitucionalismo Español, IEP, 3. ${ }^{2}$ edición, Madrid, 1974, págs. 95 y ss. y 243-254; y L. Diez del Corral, El Liberalismo Doctrinario, IEP, Madrid, 3. a edición, 1973, págs. 513-519. 
do los antiguos fueros y libertades de estos Reinos, y la intervención que sus Cortes han tenido en todos los tiempos en los negocios graves de la Monarquía modificando al efecto la Constitución promulgada en 18 de Junio de 1837, hemos venido, en unión y de acuerdo con las Cortes actualmente reunidas, en decretar $y$ sancionar la siguiente...." ${ }^{30}$.

\section{Historicismo y realismo social}

Pero, como és lógico, más que en los textos normativos, la doctrina liberal-moderada de la Constitución histórica se fue perfilando en algunos Cursos de carácter académico, en numerosos opúsculos y en diversos artículos periodísticos, aparecidos desde la muerte de Fernando VII hasta la aprobación del texto de 1845. Desde luego, la doctrina de la Constitución histórica, incluso en su versión liberal, admitió muchos matices ideológicos. Así, por ejemplo, la concepción de FRANCISCO MARTÍNEZ DE LA ROSA O de ANTONIO ALCALÁ GALIANO era sensiblemente distinta a la de DONOSO CORTÉS y JAIME BALMES. Si en el primer caso, los ingredientes liberales pesaban tanto o más que los tradicionales, en el segundo ocurría a la inversa. ALCALÁ GALIANO y MARTÍNEZ DE LA ROSA habian sido liberales toda su vida, incluso muy radicales, en algún tiempo: el primero durante la guerra de la Independencia y el segundo sobre todo durante el Trienio. En DONOSO CORTÉS, en cambio, el influjo del tradicionalismo de BONALD, MAISTRE y del primer LAMENNAIS sería muy fuerte, incluso en su etapa doctrinaria - que es la única que aquí interesa considerar- $\mathrm{y}$ desde luego en la que se inicia con su célebre Ensayo sobre el catolicismo, el liberalismo y el socialismo, que vio la luz en 1851. El papel de la Corona y de la Iglesia Católica se refuerzan considerablemente en las tesis de Jaime Balmes, un pensador equidistante del moderantismo más derechista y del carlismo más templado, en el que se percibe el fuerte impacto del pensamiento escolástico.

Ahora bien, sin desdeñar estos matices, interesa fundamentalmente en estas páginas poner de relieve los aspectos comunes a la concepción moderada de la Constitución histórica de España, entre otras cosas porque la versión más derechista de la misma sale a la luz, sobre

30 Esta fórmula, aunque abreviada, se recogería después en el Preámbulo de la Constitución de 1876, según la cual el Rey Don Alfonso Xli, "por la gracia de Dios, Rey constitucional de España», decretaba y sancionaba la Constitución "en unión y de acuerdo con las Cortes del Reino". 
todo, después de 1845, esto es, fuera del ámbito temporal de este trabajo. Una versión que, con el respaldo político del grupo de Viluma - deseoso de casar a Isabel II con el Conde de Montemolín- y con el patrocinio ideológico de BALMES, primero, y de DONOSO, después, pasaría a engrosar durante la restauración canovista el bagaje doctrinal de los "neocatólicos", mucho más cerca ya del tradicionalismo carlista que del liberalismo moderado.

De lo dicho hasta aquí se deduce que, junto a la veta jovellanista, sin duda la más importante, había otros veneros doctrinales que fueron enriqueciendo durante los años treinta y cuarenta del pasado siglo la doctrina de la constitución histórica. Entre ellos, es preciso destacar a BURKE, a los doctrinarios franceses y al historicismo romántico alemán.

BURKE influyó sobre todo en ALCALÁ GALIANO. El utilitarismo, el rechazo de los principios abstractos, la proclividad hacia la observación $y$ el análisis concreto y pormenorizado son comunes a BURKE y a GALIANO. Y en buena parte comunes son sus fuentes de información. En la teoría constitucional de GALIANO, que de forma sistemática se recoge en sus Lecciones de Derecho Político Constitucional, pronunciadas entre 1843 y 1844, es patente la influencia del pensamiento inglés. La anglofilia de GALIANO databa de lejos. Ya en su primera juventud, en su Cádiz natal, había leído con voracidad a los más destacados políticos, historiadores y economistas británicos, como MILTON, HUME, ROBERTSON, GIBBON y ADAM SMITH, lecturas bien presentes también en el pensamiento de BURKE. Sus contactos con Inglaterra se acrecentaron en el exilio de 1823 a 1833, época en la cual llegó a conocer a destacadas personalidades de la vida inglesa y a colaborar en diversas revistas, como la "Westminster Reviem", de los radicales de BENTHAM. Agradaba a GALIANO, particularmente, la concepción burkeana de la historia como paulatina acomodación de lo nuevo a lo viejo, del pasado al presente, a la vez que como juego de intereses sociales que se crean, anudan y separan para volverse, al fin, a anudar. Una visión que en gran parte respondia al propio proceso histórico británico, fluido y falto de cesuras desde la Revolución de 1688. En GALIANO, como en JOVELLANOS y en BURKE, se aprecia una decidida tendencia a conciliar la tradición con el progreso, la historia con la razón. "En los hombres -escribe en sus Lecciones- puede más lo heredado que lo adquirido, lo mamado con la leche que lo aprendido a fuerza de trabajo, de lectura, de meditaciones. En balde es que pretendamos reñir con el pasado" ${ }^{31}$. Ahora bien, prosigue GALIANO,

${ }^{31}$ Lecciones de Derecho Político Constitucional, Imprenta de D. I. Boix, Madrid, pág 30. Sobre estas Lecciones y sobre las de Donoso Cortés y Pacheco, a las que me referiré más adelante, vid. mi artículo "Tres Cursos de Derecho Político en 
"esta reverencia por la antigüedad, este deseo y anhelo de conservar... trae consigo alguno y no leves daños, puede llevar al punto de cerrar la entrada en la sociedad al espíritu de mejora" ${ }^{32}$. De ahí que, si bien el principio de progreso "fue sacado de quicio y llevado al extremo por los franceses en su primera revolución", no debía condenarse totalmente, ya que "bien regulado, contenido, atemperado, sirviendo de mezcla y freno al principio opuesto, es el que hoy entre los entendidos y cuerdos predomina; $y$ de él han de salir las leyes verdaderamente buenas, $y$ con ellas la fuerza y la buenaventura de los pueblos" ${ }^{33}$.

En la doctrina de la Constitución histórica es perceptible también la influencia de GUIZOT y en general de los doctrinarios franceses. Los doctrinarios pretenderán dotar a las instituciones liberales de una nueva legitimidad. Esta legitimidad no debía fundarse exclusivamente en la historia, como deseaban los "Ultras" franceses, ni mucho menos en las fuerzas oscuras y colectivas de un metafísico Volksgeist, como haría el romanticismo jurídico y político alemán a partir de la concepción hegeliana del Estado como "realidad de la idea moral". Ahora bien, la legitimidad de las nuevas instituciones no debía basarse tampoco en una razón ahistórica, encarnada en la Nación, desde la cual se había querido hacer en 1789 tabula rasa del pasado. Los doctrinarios tratarán de conciliar la historia y la razón, el pasado y el presente, la sociedad estamental y la sociedad burguesa, el antiguo régimen y el nuevo Estado liberal ${ }^{34}$. A partir de 1814 la tarea del liberalismo era, en frase de GUIZOT, la de "separar la causa de la realeza restaurada de la del Antiguo Régimen, y la causa de la libertad política de la de los teóricos revolucionarios $n{ }^{35}$.

No cabe duda de que esta tarea podía calificarse de ecléctica. El eclecticismo era, en realidad, uno de los componentes más destacados del nuevo liberalismo postnapoleónico, en el que bebieron los moderados españoles ${ }^{36}$. Pero más que un sistema filosófico, endeble y mediocre, expuesto por autores tan caros a los doctrinarios como VÍCTOR COUSIN y LAROMIGIĖRE, el eclecticismo era una actitud que impregnaba las diversas corrientes politicas de Francia durante la Restauración y todavía

la primera mitad del siglo XIX: Las "Lecciones" de Donoso Cortés, Alcalá Galiano y Pacheco", Revista de las Cortes Generales, n. 8, 1986.

32 Ibidem, pág. 334.

33 lbidem, pág. 344.

34 Cfr. L. Diez del Corral, El Liberalismo doctrinario, op. cit., págs. 283 y ss.

35 Apud Louls Girad, Les Liberaux Français, 1814-1875, Aubier, París, 1985, pág. 74.

36 Vid. mi artículo «El liberalismo francés después de Napoleón (de la anglofobia a la anglofilia)", REP, n. 76, Madrid, 1992. 
más durante la Monarquía de Julio (la Monarquía del juste milieu), de la misma forma que impregnaria más tarde la doctrina constitucional moderada durante la Monarquía isabelina (también durante la Monarquía alfonsina).

Pero el intento de conciliar el pasado con el presente, el Antiguo Régimen y el nuevo Estado liberal tenía unos límites bastantes precisos. Uno de ellos era la Monarquia. Forma de Estado - y no sólo de gobierno- que los doctrinarios franceses consideraban indiscutible, como antes habian hecho BURKE y JOVELLANOS y como luego harian los moderados españoles. "La Monarquía -escribe a este respecto el mejor conocedor del doctrinarismo francés-, que representa la consagración histórica del Derecho, se encuentra con una posición propia y hasta cierto punto superior al poder legislativo, que tiene una función jurídica, diriamos, bidimensional, a la que falta profundidad histórica. Una Asamblea legislativa no puede proclamarse legisladora universal ex nihilo, pretendiendo aplicar determinados principios racionales o tomando decisiones por su propia voluntad; la instancia jurídica y política del presente necesita de la que compendia el curso histórico. Para ser plenamente racional, en sentido doctrinario, el régimen representativo precisa de la dimensión histórica que representa la Monarquía. "También es mayoría — según la expresión de ROGER-COLLARD- la que se cuenta por generaciones". Por encima de la función legislativa de las Cámaras, encarnada en la Monarquía, existe una superlegalidad, una legitimidad en que se condensan determinados principios políticos $y$ morales" ${ }^{37}$.

La influencia de la concepción doctrinaria de la historia, de la politica y de la Constitución se manifiesta en El Espiritu del siglo, la obra más importante del MARTÍNEZ DE LA ROSA, que comienza a publicarse a partir de 1835. Pero esta influencia, la de GUIZOT en particular, es especialmente intensa en los primeros trabajos de DONOSO CORTÉS, como las Consideraciones sobre la Diplomacia o sus Comentarios sobre la Ley Electoral de MENDIZÁBAL y al Proyecto Constitucional de 1837, aunque el influjo del publicista francés se detecta sobre todo en sus Lecciones de Derecho Político, pronunciadas, entre 1836 y 1837, en el Ateneo de Madrid. Pese a su título, las Lecciones de DONOSO conforman un Curso de Filosofía de la Historia en el que pretende ofrecer una sólida fundamentación intelectual a la teoría política y constitucional del moderantismo. Es patente la simpatia que despierta en DONOSO GIAMBATISTA VICO, a quien en 1838 dedicaría un conjunto de artículos y cuya Scienza Nuova considera en las Lecciones, con perspicacia, como el "origen de la reno- 
vación de los estudios históricos en nuestros días" ${ }^{33}$. El influjo de SAN AGUSTÍN y BOSSUET es notable, y se acentuaría con el paso de los años, reflejándose de forma más nítida en sus Cartas de Paris, publicadas en 1842, y en sus Estudios sobre la Historia, escritos entre 1847 y 1848 , en donde se manifiesta la fuerte influencia del Discours sur l'Histoire Universelle, de BOSSUET, aunque esta influencia es sobre todo patente en el Ensayo. No obstante, el influjo más acusado es el de los doctrinarios franceses, y muy especiaimente el de GUIZOT. ("Guizotín», llamaría a DONOSO la prensa progresista). A través de este autor, asi como de VícTOR COUSSIN y de la Señora de STÄEL, se percibe también en estas Lecciones la huella de la concepción hegeliana de la historia y el eco del idealismo alemán. La tesis central que preside las Lecciones es la "soberanía de la inteligencia", que era su personal adaptación de la doctrina de la "souveraineté de la raison", ideada por ROYER-COLLARD. La soberanía de la inteligencia reviste en la historia diferentes formas y representa el motor de la concepción histórica donosiana, con un papel similar al Espíritu en HEGEL o a la lucha de clases en MARX. En siglo XIX, según DONOSO, la soberanía de la inteligencia se encarna en las "clases medias", cuyo despliegue histórico expone siguiendo muy de cerca lo dicho por GUIZOT en su Historia de la civilización en Europa. A estas clases pertenecía el ejercicio de la soberanía y particularmente el de la función electoral $^{39}$.

Otra de las fuentes ideológicas presentes en la doctrina española de la Constitución histórica era el historicismo romántico, cuya influencia es evidente en las Lecciones sobre la Historia del Gobierno y Legislación de España, que PEDRO JOSÉ PIDAL, Marqués de Pidal, dictó en el Ateneo de Madrid, entre 1841 y 1842. Estas Lecciones pretendían ser un estudio histórico de la "civilización española», siguiendo en buena parte el modelo impuesto por GUIZOT en su Historia de la civilización de Francia, aunque el curso de PIDAL, en contra de sus iniciales previsiones, no lle-

38 Lecciones de Derecho Político, 1836-1837, en Obras Completas, Biblioteca de Autores Cristianos (BAC), Madrid, 1970, t. 1.․ pág. 405.

${ }_{39}$ La tesis doctrinaria de la "soberanía de la inteligencia" la defendió el Diputado moderado SANTAELLA en las Cortes Constituyentes de 1837, quizá por influjo de Donoso: «El principio de la soberanía nacional el siglo XIX le quiere consignado en la inteligencia, en ese poder creador, en esa fuerza inventora que habrá de satisfacer las necesidades de las masas y combinar el producto de las ciencias con las ventajas de la industria. Ésta, señores, es la verdadera soberanía...". DSCC, 19 de marzo de 1837, pág. 2234. La tesis de la "soberanía de la inteligencia" se conciliaría fácilmente, según se verá más adelante, con la doctrina de la "soberanía compartida", de más raigambre española, que en estas Cortes defendieron, sin éxito, algunos Diputados moderados, como Garcia Carrasco. Cfr. DSCC, 20 de marzo de 1837, pág. 2248. 
gase más allá del período visigótico. En el cuadro general del Curso, que se contiene en la Lección primera, la más interesante y acabada de todas, PIDAL refleja, no obstante, bien que de forma esquemática, su concepción general de la historia de España, destacando en ella la importancia de la Edad Media, así como el de las dos «instituciones centrales»: la Monarquía y las Cortes, cuyo decisivo papel en la historia de España se ocupará de poner de relieve en las Cortes de 1845, según veremos ${ }^{40}$.

Destaca PIDAL la extraordinaria revitalización de los estudios históricos que se había producido desde comienzos del siglo XIX a cargo de NIEBUHR, GANZ, SAVIGNY, GUIZOT, THIERS, SISMONDI, THIERRY, CHATEAUBRIAND, BOTAL, MICALI, LINGARD Y HALLAM ${ }^{41}$. Una revitalización que era consecuencia de una plausible reacción contra el racionalismo dominante en el siglo XVIII -cuyo origen se encontraba en DESCARTES ${ }^{42}$-, en virtud del cual se había desdeñado "el mundo práctico y positivo, las instituciones existentes y la escuela experimental de los hechos que constituyen la historia». Los diversos sistemas filosóficos hegemónicos en esa centuria, proseguía PIDAL, "aunque diversos y discordes entre sí, convenían con todo unánimemente en una cosa: en condenar todo lo existente, todo lo histórico, todo lo tradicional, y en desconocer el germen de vida, que encierran siempre en su seno las instituciones que han atravesado los siglos, por caducas $y$ débiles que parezcan ${ }^{43}$.

PIDAL no niega que algunas instituciones que la llustración había puesto en la picota habían dejado de cumplir función alguna en el seno de la sociedad. Tampoco se obstina en condenar todo lo que este siglo había aportado al acerbo cultural de la humanidad. Como buen jovellanista, se limita a censurar los métodos expeditivos y traumáticos empleados en el siglo pasado, sobre todo en Francia, para transformar la sociedad, insistiendo en que "todos los grandes y verdaderos adelantos de la humanidad han consistido siempre en mejoras progresivas y prudentes, no en inconsideradas innovaciones; en perfeccionar y modificar lo existente, no en destruirlo de raízn ${ }^{44}$.

40 Destaca Pidal, asimismo, como en otro plano harian Washington Irwing y Merimé, el "saber y las ciencias" de los "árabes españoles", asi como "el espíritu oriental que hemos transmitido al resto de la Europan, Lecciones sobre la Historia del Gobierno y Legislación de España (desde los tiempos primitivos hasta la Reconquista), pronunciadas en el Ateneo de Madrid en los años de 1841 y 1842, por D. Pedro José PIDAL, Marqués de Pidal, Imprenta de la Revista de Legislación, Madrid, 1880, págs. 21-22.

4) Ibidem, pág. 2.

42 lbidem, pág. 6.

43 Ibidem, págs. 3 y 4.

44 lbidem, pág. 5. 
Ahora bien, al analizar los componentes doctrinales presentes en la doctrina de la Constitución histórica no basta con mostrar el influjo de BURKE, del doctrinarismo francés y del historicismo romántico alemán. Es preciso, además, hacer hincapié en la mixtura que en esta doctrina se detecta entre el historicismo y el realismo sociológico. Una mixtura que se hallaba in nuce en los discursos que en las Cortes de Cádiz había pronunciado INGUANZO, según se ha dicho, y que ahora está presente de forma mucho más diáfana en la mayor parte de los teóricos del moderantismo. La defensa de una supuesta constitución histórica de España, única e inalterable en lo esencial a lo largo del tiempo, iba acompañada de una no menor atención a la Constitución social o real. Se fundian, así, el influjo de BURKE, de los doctrinarios franceses y de la Escuela Histórica de SAVIGNY, con el positivismo sociológico de AUGUSTO COMTE, siempre pendiente de los intereses reales de la sociedad, y con el utilitarismo de JEREMÍAS BENTHAM. Un autor tan influyente entre los progresistas como entre los moderados, al menos desde el Trienio Constitucional ${ }^{45}$.

En realidad, el tratar de conciliar la legitimidad histórica con los intereses sociales del presente es un intento típicamente moderado, no sólo del moderantismo español. Sobre este particular ha insistido el profesor JOVEN ZAMORA. Oigamos sus palabras: "La antinomia nacida con la Revolución francesa y el romanticismo - ¿validez universal de unos principios políticos hallados por la razón, o validez específica de unos principios adaptados a unas circunstancias concretas, a un peculiar Volkgeist?- permitirá al moderantismo de todos los tiempos invocar el segundo de sus términos para cubrir con formas y prácticas políticas distintas al modelo occidental una sociedad que se desea mantener bajo el propio control. La confusión entre «peculiaridad histórico-nacional, constitutiva de una tradición», $y$ "estructura social que se desea mantener inmutable en razón de intereses de grupo", será indispensable para entender el "ulterior despliegue histórico de esta posición" ${ }^{46}$.

Al defender el orden histórico, tradicional, y las instituciones políticas que le eran consustanciales, el Rey y las Cortes, copartícipes de la soberanía, se defendían también las relaciones de poder presentes, exis-

45 Sobre la influencia de Benhtam en España y sobre la interpretación que de su filosofía se hizo en nuestro país durante la primera mitad del pasado siglo me extiendo en mi reciente Estudio Introductorio a los Principios Naturales de la Moral, de la Política y de la Legislación, de Francisco Martínez Marina, Junta General del Principado de Asturias, Oviedo, 1993.

${ }_{46}^{4}$ José M. Isabel I|", en Humanismo, Diplomacia en la España del siglo XIX, pág. 250. 
tentes. El rey y un Senado compuesto por la Nobleza terrateniente y las altas jerarquías de la Iglesia Católica, expresaban el orden histórico, el pasado, que se quería conservar; las "clases medias" salidas de la desamortización, que tenían asiento en el Congreso de los Diputados, expresaban el orden del presente, que ciertamente quería mantenerse. La soberanía del Rey y las Cortes, base de la Constitución histórica, era, pues, la soberanía de lo viejo y de lo nuevo. La Constitución histórica era también la Constitución real. El concepto histórico de Constitución se conjugaba, así, con un concepto sociológico de la misma, la doctrina de la «soberanía compartida" con la doctrina de la "soberania de la inteligencia", de una inteligencia social, concreta, histórica.

Esta mezcla de historicismo y de realismo social es patente en las Consideraciones sobre la Diplomacia, escritas por DONOSO CORTÉS en 1834. En esta obra, el pensador extremeño concibe a las constituciones, siguiendo a SAVIGNY y en general al romanticismo alemán, como resultado de las costumbres del pais, como manifestación "espontánea» de un supuesto Volkgeist, pero también como expresión de unas concretas relaciones sociales: "Las Constituciones -escribe-son las formas con que se revisten las sociedades en los distintos periodos de su historia y su existencia; y como las formas no existen por sí mismas, no tienen una belleza que les sea propia ni pueden ser consideradas sino como la expresión de las necesidades de los pueblos que las reciben... Las Constituciones, pues, no deben examinarse en sí mismas, sino en su relación con las sociedades que las adoptan. Si la razón nos dicta esta verdad, la Historia nos enseña que las sociedades tienden siempre de suyo a revestirse de la forma que le es propia y a darse la Constitución que necesitan para reposarse en un todo armonioso y consistente... Los que piensan que las Constituciones se encuentran formadas en los libros filosóficos, como las recetas de los médicos, echarán de menos en la del año 12 el equilibrio de poderes, que se ha hecho un lugar común entre todos los aprendices de la política, que sólo estudian a la Inglaterra en vez de estudiar a su país, olvidando siempre que la espontaneidad es el hecho dominante en aquella isla privilegiada y que esa misma espontaneidad en las instituciones hace imposible su transplantación (sic) a pueblos que obedecen a otras influencias..." ${ }^{47}$.

Historicismo y realismo social están presentes, asimismo, en MARTÍNEZ DE LA ROSA. EI máximo responsable de que el Estatuto Real recogiese la doctrina jovellanista de la Constitución histórica, según se ha visto, es también el mismo que mantuvo en El Espiritu del Siglo que los

47 Consideraciones sobre la Diplomacia, 1834, en Obras Completas, op. cit., págs. 248 a 250 . 
«intereses reales de la sociedad son el centro común a que deben encaminarse las constituciones políticas" ${ }^{48}$.

Igualmente, para JAIME BALMES, en quien el escolasticismo se mixtura de forma sorprendente con el influjo de BENTHAM $y$ en menor medida con el de COMTE ${ }^{49}$, la Constitución no podía reducirse a un texto jurídico más o menos solemne, ni siquiera el elemento jurídico era el más relevante a la hora de determinar la Constitución de un país. Por Constitución había que entender ante todo el conjunto de principios y costumbres seculares de un país, definitorios de su carácter nacional, así como su entramado social, esto es, las fuerzas realmente presentes y actuantes en él: "Suele llamarse ley fundamental -escribe - la que determina las formas políticas; la palabra "fundamental" induce a algunos a creer que las constituciones son lo más fundamental que hay en un país. No puede negarse que, con respecto a las instituciones civiles, son las formas politicas su verdadero fundamento; pero éstas, a su vez, han de asentarse sobre otro cimiento formado de aquella masa, digámoslo así, en cuya composición entran las ideas y costumbres del país y aquellas instituciones que por antonomasia se apellidan sociales" ${ }^{50}$. En el documento constitucional distinguía BALMES «dos partes enteramente distintas», una que califica de "fundamental» y otra de "reglamentaria»: "En vano se ha dado a todos los artículos un mismo carácter y en vano se los ha fortalecido con idéntica sanción: lo que expresa poderes sociales preexistentes a la ley es verdaderamente fundamental; lo demás es fundamental de nombre, reglamentario de hecho" ${ }^{5 !}$.

Las Lecciones de Derecho Político Constitucional, pronunciadas por ANTONIO ALCALÁ GALIANO, están transidas, asimismo, de esta doble necesidad de conjugar lo histórico y lo social, la apelación a la tradición histórica y a los intereses y necesidades sociales, en una línea muy parecida a la de BENTHAM - «mi maestro en otro tiempo, pues he se-

48 El Espíritu del Siglo, Imprenta de D. Tomás Jordán, Madrid, 1835-1839, vol. I, pág. 26.

${ }_{49}$ Además de estas fuentes doctrinales, en el pensamiento político y constitucional de Balmes se manifiesta también la influencia de la filosofía romántica de la historia, aunque ésta se detecta sobre todo en El protestantismo comparado con el catolicismo en sus relaciones con la civilización europea, en la que es evidente el influjo de El Genio del Cristianismo, de Chateaubriand. Sobre la filiación doctrinal de Balmes, vid. mi Estudio Preliminar a Jaime Balmes, Política y Constitución, CEC, Madrid, 1988, especialmente en las págs. XXV a LI.

50 Consideraciones Políticas sobre la situación de España, 1840, en Obras Completas, BAC, Madrid, 1948-1950, t. VI, pág. 53.

pág. 367.

51 Estudios Políticos: el Alto Cuerpo Colegislador, 1843, en op. cit., t. VI, 
guido su escuela, de la cual todavía no en mucho me aparto" ${ }^{52}-$ y a la de BURKE. Más que la "forma de las Constituciones", entendidas éstas como la estructura normativo-institucional del Estado, era preciso buscar, a juicio de GALIANO, su "alma" "53. Buscar el "alma" consistía en averiguar "en cuál clase están el influjo superior y el gobierno en varios estados, respectivamente" ${ }^{54}$. La estructura social, pues, era, para GALIANO, el "alma" del Estado, mientras que su "forma" equivalía "a lo llamado comúnmente Constitución", donde están declaradas y demarcadas las facultades que a las primeras potestades del Estado, respectivamente, competen" ${ }^{5}$. "Habiendo así dividido y puesto en lugares aparte el alma y el espíritu, y la parte material o la forma de los gobiernos - continuaba diciendo GALIANO-, fuerza es reconocer que a la primera de estas dos cosas debe darse la principal importancian ${ }^{56}$.

El hilo conductor de las Lecciones de Derecho Político Constitucional que pronunció JOAQUÍN FRANCISCO PACHECO en el Ateneo de Madrid, entre 1844 y 1845, consistía también en conectar la forma jurídicopolítica de los Estados constitucionales con su estructura social y en insistir en que una y otra debían acoplarse: "Cien veces recordaremos -escribe- que lo que hace buena y aceptable a una forma política es que exprese regularmente la situación social del país que la adopta ${ }^{57}$. De ahí su hincapié en afirmar la necesidad de que en los Estados constitucionales se encuentran representados los "elementos sociales" predominantes en la sociedad: "El elemento real, el elemento aristocrático y el elemento popular" ${ }^{53}$. Bien entendido que al aludir a este último "elemento social" no quería aludir a las clases de "ínfima condición", sino tan sólo a la "clase media", "poseedora de la mayor parte de la propiedad, poseedora de la inteligencia.... ${ }^{59}$.

\section{El jovellanismo como aglutinante}

Lleva, pues, razón SÁNCHEZ AGESTA cuando escribe que en la doctrina de la Constitución histórica "confluyen fuentes muy varias y tendencias de diverso significado. El concepto resultante no es por esto una

$52 \quad$ Leccionies..., op. cit., pág. 227.

53 Lecciones..., op. cit., pág 13.

54 lbidem, pág. 42.

55 Ibidem, pág. 43.

56 Ibidem, pág. 43.

57 Joaquín Francisco Pacheco, Lecciones de Derecho Político Constitucional, Imprenta de D. Ignacio Boix, Madrid, 1845, pág. 54.

${ }_{58} \quad$ lbidem, pág. 97.

59 Ibidem, págs. 231-233. 
amalgama ideológica, sino un cuerpo nuevo de doctrina, complejo, sí, pero de un sentido unitario. La soberanía de la inteligencia, la mesocracia y el sufragio censatario, el justo medio que concibe la Constitución como un pacto, es una de las fuentes que afluyen con su caudal a esta doctrina; la doctrina contrarrevolucionaria de BURKE, que opone los principios abstractos a la evolución y el contacto de la espontaneidad histórica, aderezada quizá con la salsa del tradicionalismo romántico, es otro venero que la enriquece; una curiosa actitud, que hoy llamaríamos sociológica o realista, que quiere atenerse a los hechos, concordar las instituciones políticas con las instituciones sociales, apoyarse en los intereses y poderes efectivos, es la tercera corriente con que se acopla el contenido de esta nueva concepción constitucional. Lo importante es cómo todos estos factores, el pacto, mesocracia, legitimismo, tradición, historia, poderes e intereses reales, se fundieron en ese concepto de la constitución interna, tan original como fecundo, que será el dogma del partido moderado" ${ }^{60}$.

Pero importa ahora insistir en que, fuesen cuales fuesen las diversas fuentes ideológicas y los diversos matices de la doctrina de la Constitución histórica sustentada por los moderados, éstos convergían a la hora de aceptar las claves de la formulación jovellanista, en particular la soberanía compartida entre el Rey y las Cortes, que todos los moderados defenderán en las Cortes de 1845. DONOSO, a pesar de no referirse a JOVELLANOS en sus Lecciones, recurrirá a sus tesis constitucionales -según se ha visto antes-como Secretario de la Comisión Constitucional en las Cortes de 1845. Y lo mismo harán en estas mismas Cortes, según veremos, ALCALÁ GALIANO y el MARQUÉS DE PIDAL. El jovellanismo de BALMES es incluso más patente todavía. Hasta el punto de que, en vez de hablar de la "soberanía compartida", como la mayor parte de los moderados, prefiere hablar de la soberanía del Rey, como había hecho el pensador asturiano, que sólo habia reconocido en la Nación, según queda dicho, el derecho de "supremacia» ${ }^{61}$. PACHECO, en cambio, no acepta en sus Lecciones de Derecho Político la idea de una Constitución histórica, pero sí una de sus piezas básicas, la teoría de la "sobera-

${ }_{60}$ Historia del Constitucionalismo Español, op. cit., págs. 223-4.

${ }^{61}$ A juicio del pensador catalán, en efecto, el texto constitucional debía contener el menor número de artículos. Incluso sólo dos: "Artículo 1.․: El Rey es soberano. Artículo 2.o: La Nación en Cortes otorga los tributos e interviene en los negocios arduos". Reforma de la Constitución, 1844, en Obras Completas, op. cit., t. VI, pág. 29. No obstante, de forma poco coherente, coincide con el constitucionalismo moderado al sostener que el Rey por sí mismo no podia variar las leyes fundamentales más que con el concurso de las Cortes. De ahí que se manifestase contrario al "sistema de las Cartas otorgadas" y partidario en cambio del Preámbulo de la Constitución de 1845. Cfr. ibidem, págs. 628, 884-5, 931 y 943. 
nía compartida" entre el Rey y las Cortes, o de la "soberanía parlamentarian, como él prefiere decir, de clara raigambre jovellanista.

El jovellanismo, pues, era el punto de unión, de encuentro de la concepción histórica del moderantismo español de mediados del siglo pasado y de su aplicación a la teoría constitucional. "Sociedad Española de Jovellanos" se denominaba la sociedad, un si es no es secreta, que los moderados fundaron tras la aprobación del texto constitucional de 1837. En su Historia de España, Antonio Alcalá Galiano explica el porqué de esta denominación: "Denominóse la nueva sociedad de Jovellanos, queriendo con la memoria de un hombre insigne simbolizar las doctrinas por él profesadas, en que iban hermanadas el culto de lo antiguo con el de lo moderno; la reverencia al Monarca con el miramiento y la atención convenientes a los derechos del pueblo, en suma, el cuidado de lo que se apellida libertad con el interés y la gloria del Trono que de ella misma es seguro amparo" ${ }^{62}$.

\section{La consolidación de la doctrina de la Constitución histórica en las Cortes de 1845}

La doctrina de la Constitución histórica se aquilató en las Cortes reformistas de 1844-1845. Allí se fijó de forma prácticamente definitiva, sin más añadidos posteriores dignos de tenerse en cuenta que los que le haría ANTONIO CÁNOVAS DEL CASTILLO en la segunda mitad del siglo pasado. No debe olvidarse que así como en las Cortes constituyentes de 1836-1837 había estado presente la plana mayor del partido progresista, desde AGUSTÍN DE ARGÜELLES a SALUSTIANO DE OLÓZAGA, en las Cortes reformistas de 1844-1845 toman asiento los más destacados exponentes del partido moderado, que monopolizó prácticamente todo el debate constitucional. Un debate que por momentos alcanzó una altura intelectual considerable. Allí coincidieron, entre otros, MARTíNEZ DE LA ROSA, ALCALÁ GALIANO, PIDAL, POSADA HERRERA, ISTÚRIZ, PACHECO y DONOSO CORTÉS, que fue nombrado Secretario de la Comisión Constitucional.

En estas Cortes, SEIJAS insistió en los dos rasgos -inseparablemente ligados - consustanciales a esta doctrina: la ausencia de un concepto de Constitución en sentido formal y el reconocimiento de un simple texto jurídico posterior e inferior a la "verdadera» Constitución, esto

62 Historia de España, t. VII, Madrid, 1946, pág. 441. 
es, a la constitución histórica (o, como se diría más tarde en España, recogiendo la influencia de MORTATI, a la Constitución "material» o "sustancial"). La Constitución formal podía variarse, al igual que una ley ordinaria; la segunda, en cambio, era intocable: "Necesario es, pues -decía este Diputado-, que distingamos entre la Constitución y la Carta constitucional... La Constitución de los Estados no varía, porque ella está fuera del tiro de los hombres. Pueden reformarse las Cartas Constitucionales, porque, como he dicho, éstas no son otra cosa que la fórmula abreviada, escrita, de esas relaciones, que sirven de base a los Estados... Nuestra competencia está limitada únicamente a establecer esa fórmula que representa la historia del país" ${ }^{63}$.

EI MARQUÉS DE PIDAL, por su parte, insistió en un punto ciertamente decisivo, a saber: la Constitución histórica, que reposaba en las dos grandes instituciones, el Rey y las Cortes, suponía una legalidad previa y superior a la Constitución formal, que no era más que una mera «ley secundaria», que debía limitarse a "arreglar» las relaciones entre aquellas dos instituciones: "El Trono y la Asamblea; he ahi los dos grandes polos sobre los que gira la Monarquía española; y es imposible que una ley secundaria, cual es la que hace la repartición de estas dos grandes legitimidades, sea superior ni igual a una de ellas. Todo lo que arregla las relaciones entre los poderes es inferior en mucho al Trono, es inferior en mucho a la representación nacional, y de consiguiente la ley política, que en el año 37 no hizo más que eso, es infinitamente inferior al Trono" ${ }^{64}$.

La Constitución formal, al igual que la histórica o material, no era fruto de la voluntad unilateral de la Nación, sino de las Cortes con el Rey. En rigor, la Constitución formal no era ley, sino contrato, con lo cual el dualismo jurídico preliberal de los moderados era manifiesto: "Considero y consideraré siempre a las Constituciones - decía POSADA HERRERA - un contrato entre el Monarca y el pueblo" ${ }^{65}$.

Ahora bien, la Constitución material o histórica, pese a haber surgido del acuerdo de las dos grandes instituciones históricas, transcendía su misma voluntad, la historia se apropiaba de ella y a la historia era preciso plegarse: "Vamos a reunir y afirmar nuestras leyes fundamentales, no dando ese nombre a las que no lo sean, las que realmente lo son argumentaba el balmista ISLA FERNÁNDEZ - no las han hecho algunos hombres, sino el tiempo, las generaciones, el estado, circunstancias, intereses y necesidades de los pueblos, son superiores al poder de los

63 $D S C$ (Congreso), 2 de noviembre de 1844.

64 Ibidem, 30 de octubre de 1844.

65 Ibidem, 12 de noviembre de 1844. 
hombres sin el auxilio del tiempo, y no es lícito poner en ellas temerariamente la mano" ${ }^{66}$.

Una de las más importantes consecuencias que se extraen en 1845 de la doctrina de la Constitución histórica y de la soberanía compartida - ambas inseparables - es, al igual que habían hecho JOVELLANOS y los realistas del doce, la de negar la existencia misma del poder constituyente: "Las Cortes con el Rey - señalaba DONOȘO CORTÉS, como Secretario de la Comisión Constitucional-son la fuente de las cosas legítimas; su potestad alcanza a todo, menos a aquellas leyes primordiales cuales nada puede intentarse que no sea nulo de toda nulidad, porque son como los fundamentos de las sociedades humanas; por ellas, después de Dios, viven perpetuamente los pueblos: con su calor y abrigo se engrandecen las naciones y debajo de su amparo reinan los reyes" ${ }^{67}$.

Y SEIJAS, en el debate parlamentario, explayándose de nuevo sobre estas premisas, sería todavía más explícito al conectar la doctrina de la soberanía compartida y la de la constitución histórica con la negación de la teoría del poder constituyente: "Fijemos la vista en nuestra España - decía- y veremos que al nacer esta Nación nació con dos instituciones capitales que le han servido de base y fundamento: el Trono $y$ las Asambleas Nacionales... nuestra competencia (la de las Cortes), nuestra facultad, señores, está limitada a establecer esa fórmula que representa la historia del pais, las relaciones de las grandes instituciones; y cuando esa fórmula adolece de vicios, cuando todos reconocemos que no representa la historia... entonces llenamos un gran deber tocando esa fórmula y renovándola... En una sociedad constituida, en una sociedad que tiene leyes, que tiene instituciones tan añejas como la sociedad misma, no es posible que reconozcamos este poder bastardo (el poder constituyente)" ${ }^{68}$.

66 Ibidem, 13 de noviembre de 1844.

67 Ibidem, 5 de noviembre de 1844.

68 Ibidem, 2 de noviembre de 1844. Esto es, como escribe Diez del Corral, "la copartición de la soberanía entre el Rey y las Cortes... no significa tan sólo suma que trate comprometidamente de resolver la antinomia planteada entre soberanía popular y monárquica, sino que apunta ambiciosamente a la clave de la misma de todo el derecho político revolucionario: la teoría del poder constituyente. No basta contraponer a la soberanía del pueblo otra que se dé en el mismo plano, sino que es preciso destruirla en sus mismas raices: el supuesto de una instancia politica suprema, desligada de todo orden superior, llamada a estructurar ex nihilo la vida del Estado... Negándose la existencia del poder constituyente sensu stricto, no cabe admitir que se pueda dar una Constitución enteramente nueva; sólo es posible que se reforme la existente de antiguon. Op. cit., págs. 576-7. 
Estas tesis desembocarían en la defensa de la flexibilidad constitucional o en la de la "omnipotencia parlamentaria", como entre nosotros se llamó durante el siglo XIX, en virtud de la cual el texto constitucional formal debia ser reformado por el mismo procedimiento y por el mismo órgano que las leyes ordinarias. Ni distinción, pues, entre poder y constituyente y poder legislativo, ni entre leyes constitucionales y leyes ordinarias. Este postulado que, como se ha dicho, se había defendido de forma implícita en Cádiz por parte de los realistas, se haría explícito en las Cortes de 1845. De hecho, ni el Estatuto Real de 1834 ni la Constitución de 1845 (ni tampoco, no se olvide, la Constitución "transaccional" de 1837) incluían un procedimiento especial de reforma constitucional, como no lo haría tampoco la Constitución canovista de 1876.

En el "Dictamen de la Comisión de Reforma de la Constitución de 1837 ", en el que tanto tuvo que ver la pluma de DONOSO CORTÉS, la "omnipotencia parlamentaria" se defendía con estas palabras: "La potestad constituyente no reside sino en la potestad constituida, ni ésta es otra en nuestra España sino las Cortes con el Rey. Lex fit consensu populi et Constitutionis Regis. Esta máxima de nuestros padres, sublime por su sencillez, ha llegado hasta nosotros vencedora de los tiempos y de las revoluciones. La Comisión (de reforma constitucional) la ha aceptado, y la proclama aqui con un profundo acatamiento" ${ }^{69}$.

Y en este mismo Congreso, MARTíNEZ DE LA ROSA, abundando en esta importante premisa, afirmó: "Todos reconocemos que corresponde a la Corona y a las Cortes el derecho de reformar la Constitución del Estado. Hubo un tiempo en que prevaleció la opinión contraria en que se establecían los medios para reformar las Constituciones, sin tener en cuenta que no hay ejemplo en la historia de una Constitución que haya sido modificada por los trámites que para ellos se establecieron... No hay nación que no tenga la facultad de reformar las fundamentales como las otras leyes, aunque con más detenimiento" ${ }^{70}$.

Al defender la doctrina de la Constitución histórica, tampoco faltó en estas Cortes la referencia a la Constitución real o social, mixturándose de nuevo el historicismo y el sociologismo, el concepto histórico de Constitución con un concepto sociológico de la misma, similar al de VON STEIN o al de LASALLE. Un concepto que ANTONIO ALCALÁ GALIANO enunciaría en estas Cortes con más claridad que en sus Lecciones: "Yo entiendo por Constitución de un Estado - decía- no sólo lo que han entendido otros, que limitan este nombre a lo que contiene el texto de un

70 Ibidem, 11 de noviembre de 1944. 
libro, bajo cuyas disposiciones se forman las leyes, sino el conjunto de lo que real y verdaderamente constituye al país; y algo de eso suele estar fuera del mismo texto, así como también suele haber dentro de él algo que no puede mirarse como propiamente constitutivo... La bondad de una Constitución -añadía- está en transformar exactamente el poder social en poder políticon" ${ }^{71}$.

En esta misma línea y en estas mismas Cortes, otro Diputado, RODRÍGUEZ BAAMONDE, recordaría que "todo poder político para que sea bien recibido, para que encuentre apoyo en la sociedad, es preciso que sea poder social; la gramática no hace la lengua, sino que recoge, fija y determina las reglas; toda Constitución debe recoger del mismo modo todos los poderes sociales, todas las influencias fuertes, naturales y legítimas que ella puede encerrarn" ${ }^{72}$.

Historicismo y realismo social se reunían, asi, de forma inescindible en la teoría constitucional del moderantismo español. La Constitución no debía consagrar sólo una supuesta tradición histórica, sino también unas relaciones sociales presentes, vigentes, actuantes. Éste era, en último término, el principio más relevante de la teoría constitucional del liberalismo moderado, desde su formulación inicial por JOVELLANOS, a partir del concepto premoderno de "leyes fundamentales", hasta la Constitución de 1845 y, en rigor, hasta CANOVAS DEL CASTILLO y el liberalismo conservador de la Restauración.

72 Ibidem, 16 de noviembre de 1844. 